\title{
OcCuRRence of Weeds in Cassava savanna Plantations in RORAIMA $^{1}$
}

\author{
Ocorrência de Plantas Daninhas em Plantios de Mandioca na Savana de Roraima
}

\author{
ALBUQUERQUE, J.A.A. ${ }^{2}$, EVANGELISTA, M.O. ${ }^{2}$, MATES, A.P.K. ${ }^{2}$, ALVES, J.M.A. ${ }^{2}$, OLIVEIRA, N.T. ${ }^{2}$, \\ SEDIYAMA, T. ${ }^{3}$, and SILVA, A.A. ${ }^{3}$
}

\begin{abstract}
A phyto-sociological survey is the first step to implement integrated weed management in crops. In this study, weed occurrence was evaluated in cassava plantations in the savannah of Roraima in northern Brazil. Harvest was performed randomly 80 times in 10 crops over four seasons (January, February, March, and April 2012). The harvested plants were cut at ground level, sorted out per species, identified, quantified, and weighed on a $0.01 \mathrm{~g}$ precision scale. A descriptive analysis was conducted of the phyto-sociological parameters (frequency, density, abundance, total number of individuals per species, relative frequency, relative density, relative abundance and importance value index) for the collected species. A description was also made of the botanical classes, families, species, type of propagation, life cycle, growth habit, total number of species and dry weight ha ${ }^{-1}$. The community in the surveyed area was considered to have a heterogeneous composition, comprising 27 species. The species presenting the highest density per hectare were Digitaria sanguinalis $(210,500)$, Brachiaria brizantha $(111,000)$, Brachiaria decumbens $(86,500)$ and Brachiaria humidicola (69,000). Digitaria sanguinalis had the highest relative density (28.08), relative abundance (26.16) and importance value index (65,34). Most weeds had herbaceous growth habit.
\end{abstract}

Keywords: Manihot esculenta Crantz, weeds, phytosocial study, savannah, morphological characteristics.

RESUMO - O levantamento fitossociológico é o primeiro passo para implantação do manejo integrado das plantas daninhas em culturas. Neste trabalho, objetivou-se avaliar a ocorrência de plantas daninhas em plantios de mandioca na savana de Roraima. As coletas das plantas foram realizadas aleatoriamente 80 vezes em 10 lavouras, em quatro épocas (janeiro, fevereiro, março e abril de 2012). As plantas coletadas foram cortadas ao nivel do solo e, depois disso, separadas por espécie, identificadas, quantificadas e pesadas em balança de precisão de 0,01 $\mathrm{g}$. Em seguida foi feita a análise descritiva dos parâmetros fitossociológicos (frequência, densidade, abundância, número total de indivíduos por espécie, frequência relativa, densidade relativa, abundância relativa e indice de valor de importância) para as espécies coletadas. Além destes parâmetros, foram descritas as classes botânicas, famílias, espécies, tipo de propagação, ciclo de vida, hábito de crescimento, número total de espécies e massa seca por hectare. A composição da comunidade da área levantada foi considerada heterogênea, apresentando 27 espécies. As espécies que apresentaram a maior densidade por hectare foram: Digitaria sanguinalis (210.500), Brachiaria brizantha (111.000), Brachiaria decumbens (86.500) e Brachiaria humidicola (69.000). Digitaria sanguinalis obteve maiores densidade relativa $(28,08)$, abundância relativa $(26,16)$ e indice de valor de importância (65,34). A maioria das plantas daninhas apresentou hábito de crescimento herbáceo.

Palavras-chave: Manihot esculenta Crantz, plantas infestantes, estudo fitossociológico, cerrado, características morfológicas.

Recebido para publicação em 10.9.2013 e aprovado em 3.11.2013.

UFRR, Boa Vista-RR, Brazil, <anchietaufrr@gmail.com>; ${ }^{3}$ Universidade Federal de Viçosa, Viçosa-MG, Brazil.

Planta Daninha, Viçosa-MG, v. 32, n. 1, p. 91-98, 2014 


\section{INTRODUCTION}

Cassava has a broad adaptation to different soil and climate conditions, being cultivated in Brazil from the states of Roraima to Rio Grande do Sul. In Roraima, cassava is grown by most small farmers and occupies an area of 6,210 ha. The average productivity of this State is $13,308 \mathrm{~kg} \mathrm{ha}^{-1}$ of roots - lower than the national average of $14,153 \mathrm{~kg} \mathrm{ha}^{-1}$ (IBGE, 2012). In this State, almost all of the roots harvested are for household consumption (Albuquerque et al., 2009). Among the by-products of cassava household consumption is flour, which has broad local acceptance, predominantly "farinha d'água" (yellow flour), coarse textured, with estimated per capita consumption of over $50 \mathrm{~kg} \mathrm{hab}^{-1}$ per year (Barbosa et al., 2007).

Among the factors responsible for the low productivity of cassava in Roraima, and also in Brazil, the inadequate management of weeds stands out. If not controlled properly, in addition to competing for key factors (light, water and nutrients), these weeds also adversely affect the harvesting operation and depreciate the quality of the product, serving also as intermediate hosts for insects, nematodes and disease-causing agents (Scholten, 2011). The cassava crop is highly susceptible to competition with weeds, as shown in studies done by Albuquerque et al. (2008), in the municipality of Viçosa-MG, where productivity losses of cassava roots without weed control reached $100 \%$. The weeds present in cassava planting can depreciate the quality and yield of a crop, difficult harvest and, in extreme cases, make it impracticable (Guglieri-Caporal, 2009). There are several reports of producers in Brazil who were bitten by venomous animals while harvesting their roots, especially in fields with high weed incidence.

This high sensitivity of the cassava crop to the interference of weeds is due to its slow initial growth in this phase, exerting little coverage of the soil, allowing the growth of weeds (Silva et al. 2007). Amanullah et al. (2006) suggest the application of chicken manure (compost $10 \mathrm{t} \mathrm{ha}^{-1}$ ) in order to increase the rate of crop growth and, consequently, the leaf area index, anticipating and shading weeds and inhibiting their growth.
According to Concenço et al. (2013), the phytosociological study, in simple terms, is a group of methods for ecological assessment, aimed at providing a comprehensive overview of the composition and distribution of plant species in a plant community. The progress of phytosociological studies, has been going slowly and not synchronized in different research groups in the country. Overall, one of the main reasons for this difference seems to be the low number of researchers are placed in different regions of Brazil (GIEHL; BUDKE, 2011). All phytosociological study is based on the morphology of plants (SOUZA et al. 2003). These methods, originally described and developed by Guglieri-Caporal et al. (2010) and Fialho et al. (2011), now constitute an important tool for the implementation of the integrated management of weeds. This is explained because, according to Malik et al. (2007) and Pielou (1975), certain communities may consist of few species, while others have hundreds of species. From the agricultural point of view, knowledge of species diversity is fundamental to understanding the dynamics of weeds versus crops (Albuquerque et al., 2012).

According to Cruz et al. (2009), it is important and necessary to identify the weed species, because each one has the potential to establish itself in the area and their aggressiveness can interfere differently across cultures. At each collection time, some species stand out due to several factors, including: characteristics of the species, climate, seed bank, crop development and control time (Albuquerque et al., 2008). In the process, more easily controllable factors in practice are the extension of the period of coexistence between cultures and weeds (PITELLI, 1985).

Thus, the removal of weeds enables decision making and the establishment of the most appropriate control methods, be they cultural, mechanical, physical, biological, chemical of integrated management. Moreover, it allows to establish an order of priority between the species present, so that a control program is determined (Kuva et al., 2007).

Given the above, the aim of this study was to evaluate the occurrence of weeds in crops of cassava in the savannah of Roraima. 


\section{MATERIALS AND METHODS}

The research was conducted in the rural district of Monte Cristo, located near the Roraima state capital, Boa Vista. The State of Roraima is located in the extreme north of Brazil, between parallels $5^{\circ} 16^{\prime}$ and $1^{\circ} 25^{\prime}$ north and south of the Equator, respectively, and between the meridians 58 $53^{\prime}$ east and 64⒋ west of Greenwich, altitude ranging from $90 \mathrm{~m}$ to $2,875 \mathrm{~m}$. It has a total area of $230.104 \mathrm{~km}^{2}$, occupying a part of the Amazon basin, representing $8 \%$ of the Legal Amazon, $6.4 \%$ of the North region and $3 \%$ of the Brazilian territory (Albuquerque et al., 2009).

The choice of study site took into account the fact that it is an area near the capital, Boa Vista, with a reasonable cassava crop area: approximately 100 hectares. 10 properties were selected at random, with total area of 40 hectares. The collections of weeds were made between January and April 2012. For sampling, we used an iron square with dimensions of $0.50 \times 0.50 \mathrm{~m}$, randomly tossed 80 times over the cassava crops during the four months, with 20 samples per month. The plants of each sample were cut at ground level and brought to the Laboratory of Great Cultures of the CCA/UFRR, where they were separated by species, counted and then taken to an oven with forced air circulation with a temperature of $65^{\circ} \mathrm{C}$, until they reached constant weight.

With this data, the descriptive analysis of the following phytosociological parameters for the species was performed: frequency $(\mathrm{Fr})=$ number of plots containing the species/ total number of plots used; density $(\mathrm{De})=$ total number of individuals per species/total area collected; abundance $(\mathrm{Ab})=$ total number of individuals per species/total number of plots containing the species; relative frequency $(F r R)=$ frequency of the species $\times 100 /$ total frequency of all species; relative density $($ DeR $)=$ density of the species $\times 100 /$ total density of all species; relative abundance $(A b R)=$ abundance of the species $\times 100 /$ total abundance of all species; and importance value index $(\mathrm{IVI})=\mathrm{FrR}+\mathrm{DeR}+\mathrm{AbR}$ (MuellerDombois \& Ellemberg, 1974). In addition to the phytosociological parameters evaluated, were described: scientific name, common name, family, plant class, total species per hectare, dry weight, type of spread, life cycle and growth habit of the weed species present in the area.

\section{RESULTS AND DISCUSSION}

The composition of the infesting community of weeds in the raised area was considered heterogeneous, with 27 species distributed in eight plant families. The genus Brachiaria presented the greatest number of species, with a total of four: brizantha, humidicola, dracunculifolia and decumbens (Table 1). The three plant families with higher occurrence were: Poaceae (Gramineae), Fabaceae (Leguminosae) and Asteraceae (Compositae), with the respective percentages: 29.69, 22.22 e $14.81 \%$ (Table 1).

Many of these families and species are commonly found in cassava crops and the most frequent were: Amaranthaceae, Cyperaceae, Commelinaceae and Poaceae and the species Amaranthus viridis, Cyperus rotundus, Commelina benghalensis, Brachiaria decumbens, Cenchrus echinatus and Digitaria horizontalis (Pinotti et al., 2010).

The class of dicotyledons had approximately $60 \%$ of the species identified (Table 1). Albuquerque et al. (2012), evaluating the occurrence of weeds after the growth of corn in the cerrado of Roraima, obtained similar results with regard to the percentage of botanical classes, although the species with the highest number of individuals per hectare have been monocotyledons (Cyperus rotundus 233,000 and Brachiaria humidicola - 49,000).

Cruz et al. (2009) conducted a survey of weeds in field crops rotated with soybean, corn and irrigated rice also in the cerrado of Roraima and found that the composition of the weed community in the area raised presented 23 species in 23 genera and 15 plant families. The families with higher prevalence were Amaranthaceae, Euphorbiaceae and Poaceae (Gramineae). In studies done by Albuquerque et al. (2008) in the municipality of ViçosaMG, assessing weed interference on the productivity of cassava, the composition of the weed community in the experimental area was of 37 species in 30 genera and 14 families. The families with higher prevalence were Asteraceae (Compositae), Poaceae (Gramineae) and Amaranthaceae. 
Table 1 - Plant classes (PC), families (FA), scientific names (SN), common names (CN) and abbreviations (Abb) (Lorenzi, 2008) of the 27 weed species collected in cassava crops in the cerrado of Roraima, 2012

\begin{tabular}{|c|c|c|c|c|}
\hline $\mathrm{PC}$ & FA & SN & $\mathrm{CN}$ & $\mathrm{Abb}$ \\
\hline \multirow{16}{*}{ Dicotiledoneae } & \multirow{4}{*}{ Asteraceae } & Acanthospermum australe & Creeping starbur & ACNAU \\
\hline & & Ageratum conyzoides & Tropical whiteweed & AGECO \\
\hline & & Blainvillea rhomboidea & Para cress flower & BLARH \\
\hline & & Emilia coccinea & Scarlet tasselflower & EMICO \\
\hline & Convolvulaceae & Merremia cissoides & Roadside woodrose & MRRCI \\
\hline & \multirow{3}{*}{ Euphorbiaceae } & Chamaesyce hirta & Pillpod sandmat & EPHHI \\
\hline & & Croton glandulosus & Vente con migo & CVNGL \\
\hline & & Euphorbia heterophylla & Fire on the mountain & EPHHL \\
\hline & \multirow{6}{*}{ Fabaceae } & Crotalaria incana & Shakeshake & CVTIN \\
\hline & & Desmodium incanum & Zarzabacoa & DEDIN \\
\hline & & Desmodium tortuosum & Dixie ticktrefoil & DEDTO \\
\hline & & Indigofera hirsuta & Hairy indigo & INDHI \\
\hline & & Mimosa pudica & Shameplant & MIMPU \\
\hline & & Senna occidentalis & Septicweed & CASOC \\
\hline & \multirow{2}{*}{ Malvaceae } & Sida cordifolia & Country mallow & SIDCO \\
\hline & & Sidastrum micranthum & Dainty Sand Mallow & SIDMI \\
\hline \multirow{11}{*}{ Monocotiledoneae } & Commelinaceae & Commelina benghalensis & Benghal dayflower & COMBE \\
\hline & \multirow{2}{*}{ Cyperaceae } & Cyperus flavus & Inflatedscale flatsedge & CYPFL \\
\hline & & Cyperus iria & Ricefield flatsedge & CYPIR \\
\hline & \multirow{8}{*}{ Poaceae } & Braccharis dracunculifolia & Chilca & BRADR \\
\hline & & Brachiaria brizantha & Palisade grass & BRABR \\
\hline & & Brachiaria decumbens & Spreading liverseed grass & BRADC \\
\hline & & Brachiaria humidicola & Koronivia grass & BRAHU \\
\hline & & Digitaria horizontalis & Jamaican crabgrass & DIGHO \\
\hline & & Digitaria sanguinalis & Hairy crabgrass & DIGSA \\
\hline & & Panicum maximum & Guinea grass & PANMA \\
\hline & & Rottboellia exaltata & Itchgrass & ROOEX \\
\hline
\end{tabular}

According to Embrapa (2005), surveys conducted in Minas Gerais and Bahia identified over 200 species, representing over 100 genera belonging to over 40 families, including monocotyledons and dicotyledons. The most frequent were Asteraceae (Compositae), Poaceae (Gramineae), Fabaceae (Leguminosae), Rubiaceae, Malvaceae, Euphorbiaceae, Convolvulaceae, Portulaceae, Amaranthaceae, Commelinaceae and Cyperaceae.

Some of the weed species that occur in cassava crops can be considered as a local or regional problem, as each region has its peculiarity regarding predominant weeds, although many of them occur together within the different cassava producing regions in
Brazil. Even in studies conducted in different regions, the plant families Poaceae, Fabaceae and Asteraceae stood out in relation to the others.

These studies should be conducted in several producing regions, but also during several growing seasons, because the composition of the weed community differs between seasons and locations (Albuquerque et al., 2008).

The species with the largest number of plants per hectare were: Digitaria sanguinalis $(210,500)$, Brachiaria brizantha $(111,000)$, Brachiaria decumbens $(86,500)$, Brachiaria humidicola $(69,000)$ e Brachiaria dracunculifolia $(40,500)$ belonging to the class of monocotyledons, while the dicotyledon species 
showed a low number per hectare (Table 2). The species with the highest values of dry weight $\left(\mathrm{g} \mathrm{ha}^{-1}\right)$ were Digitaria sanguinalis $(112,530)$, Brachiaria Brizantha $(98,000)$, Brachiaria decumbens (73 795) and Brachiaria humidicola $(42,780)$ (Table 2).

The species with the highest frequencies were Commelina benghalensis and Digitaria sanguinalis, being found in almost all samples. Digitaria sanguinalis showed higher values of density, abundance, number of plants per hectare and higher accumulation of dry weight (Table 2). A significant portion of the production cost of cassava can be attributed to weed control, which may vary according to weed species and their population densities (Aguiar et al., 2011).
The species Commelina benghalensis showed the highest relative frequency (13.30) while Digitaria sanguinalis had a higher relative density (28.08), relative abundance (26.16) and importance value index (65.34) (Figure 1).

Huziwara et al. (2009), in a phytosociological survey of weeds in cassava crop in the municipality of Campos dos Goytacazes, identified only 10 species, mainly Cyperus rotundus, which showed and Importance Value Index (IVI) of 111 , followed by Commelina benghalensis, Sorghum arundinaceum, with IVI of 67 and 50, respectively. Now Pinotti et al. (2010) found the highest importance value index obtained for the species Brachiaria decumbens and Digitaria horizontalis.

Table 2 - Frequency (Fr), density (De), abundance (Ab), number of plants per ha-1 (NP) and dry weight (DW, g ha ${ }^{-1}$ ) of the 27 weed species collected in cassava crops in the cerrado of Roraima, 2012

\begin{tabular}{|c|c|c|c|c|c|}
\hline $\mathrm{SN}$ & $\mathrm{Fr}$ & $\mathrm{De}$ & $\mathrm{Ab}$ & NP & DW \\
\hline Digitaria horizontalis & 0.32 & 7.44 & 1.86 & 46,500 & 34,675 \\
\hline Rottboellia exaltata & 0.16 & 0.56 & 0.14 & 3,500 & 41,105 \\
\hline Cyperus iria & 0.32 & 8.56 & 2.14 & 53,500 & 28,380 \\
\hline Croton glandulosus & 0.24 & 0.24 & 0.06 & 1,500 & 9,070 \\
\hline Crotalaria incana & 0.08 & 0.08 & 0.02 & 500,000 & 6,030 \\
\hline Brachiaria brizantha & 0.40 & 17.76 & 4.44 & 111,000 & 98,000 \\
\hline Ageratum conyz oides & 0.08 & 0.16 & 0.04 & 1,000 & 1,390 \\
\hline Digitaria sanguinalis & 0.80 & 33.68 & 8.42 & 210,500 & 112,530 \\
\hline Commelina benghalensis & 0.96 & 7.44 & 1.86 & 46,100 & 26,170 \\
\hline Sidastrum micranthum & 0.08 & 2.32 & 0.58 & 14,500 & 16,155 \\
\hline Sida cordifolia & 0.24 & 2.00 & 0.50 & 12,500 & 12,655 \\
\hline Euphorbia het erophylla & 0.24 & 1.60 & 0.40 & 10,000 & 13,340 \\
\hline Mimosa pudica & 0.16 & 0.16 & 0.04 & 1,000 & 6,385 \\
\hline Acanthospermum australe & 0.16 & 2.32 & 0.58 & 14,500 & 13,340 \\
\hline Brachiaria humidicola & 0.40 & 11.04 & 2.76 & 69,000 & 42,780 \\
\hline Braccharis dracunculifolia & 0.32 & 6.48 & 1.62 & 40,500 & 37,765 \\
\hline Cyperus flavus & 0.48 & 0.88 & 0.22 & 5,500 & 10,665 \\
\hline Chamaesyce hirta & 0.24 & 0.8 & 0.20 & 5,000 & 4,780 \\
\hline Indigofera hirsuta & 0.08 & 0.08 & 0.02 & 500,000 & 1,820 \\
\hline Emilia coccinea & 0.16 & 0.56 & 0.14 & 3,500 & 4,710 \\
\hline Senna occidentalis & 0.08 & 0.08 & 0.02 & 500,000 & 3,895 \\
\hline Desmodium inca num & 0.16 & 0.16 & 0.04 & 1,000 & 13,430 \\
\hline Desmodium tortuosum & 0.08 & 0.08 & 0.02 & 500,000 & 11,430 \\
\hline Brachiaria decumbens & 0.32 & 13.84 & 3.46 & 86,500 & 73,795 \\
\hline Blainvillea rhomboidea & 0.24 & 1.20 & 0.30 & 7,500 & 8,085 \\
\hline Panicum maximum & 0.32 & 7.36 & 1.84 & 46,000 & 32,470 \\
\hline Merremia cissoides & 0.24 & 1.84 & 0.46 & 11,500 & 7,785 \\
\hline
\end{tabular}




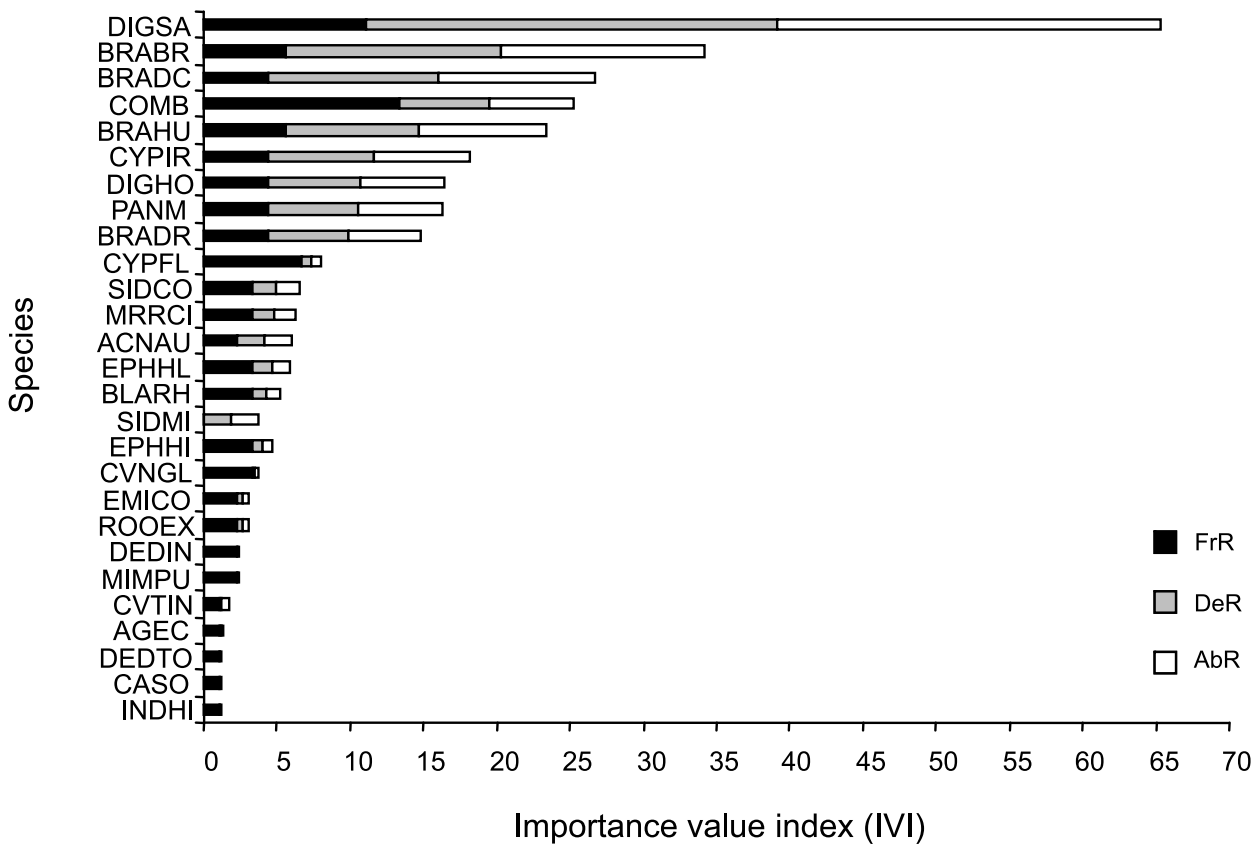

Figure 1 - Relative frequency (FrR), relative density (DeR), relative abundance (ABR) and importance value index (IVI) of the 27 weed species collected in cassava crops in the cerrado of Roraima, 2012.

Table 3 - Type of propagation (TP), life cycle (LC) and growth habit (GH) of the 27 weed species collected in cassava crops in the cerrado of Roraima, 2012

\begin{tabular}{|c|c|c|c|}
\hline SN & TP & LC & $\mathrm{GH}$ \\
\hline Acanthospermum australe & Seeds (Exclusively) & Annual & Herbaceous \\
\hline Ageratum conyzoides & Seeds (Exclusively) & Annual & Herbaceous \\
\hline Blainvillea rhomboidea & Seeds (Exclusively) & Annual & Herbaceous dichotomous \\
\hline Braccharis dracunculifolia & Seeds, Stolons and Rhizomes & Perennial & Erect herbaceous, grows in bunches \\
\hline Brachiaria brizantha & Seeds & Perennial & Erect herbaceous, grows in bunches \\
\hline Brachiaria decumbens & Seeds, Stolons and Rhizomes & Perennial & Erect herbaceous, grows in bunches \\
\hline Brachiaria humidicola & Seeds, Stolons and Rhizomes & Perennial & Erect herbaceous, grows in bunches \\
\hline Chamaesyce hirta & Seeds (Exclusively) & Annual & Herbaceous \\
\hline Commelina benghalensis & Normal seeds and formed in rhizomes & Perennial & Herbaceous, semi-succulent \\
\hline Crotalaria incana & Seeds & Perennial & Herbaceous \\
\hline Croton glandulosus & Seeds & Annual & Herbaceous-woody \\
\hline Cyperus flavus & Seeds (Exclusively) & Annual & Erect herbaceous \\
\hline Cyperus iria & Seeds (Exclusively) & Annual & Erect herbaceous \\
\hline Desmodium incanum & Seeds & Perennial & Herbaceous \\
\hline Desmodium tortuosum & Seeds & Perennial & Herbaceous \\
\hline Digitaria horizontalis & Seeds and Stolons & Annual & Erect herbaceous, grows in bunches \\
\hline Digitaria sanguinalis & Seeds and short rhizomes & Annual & Herbaceous \\
\hline Emilia coccinea & Seeds (Exclusively) & Annual & Herbaceous \\
\hline Euphorbia heterophylla & Seeds & Annual & Herbaceous \\
\hline Indigofera hirsuta & Seeds (Exclusively) & Annual/Perennial & Herbaceous \\
\hline Merremia cissoides & Seeds & Annual & Herbaceous \\
\hline Mimosa pudica & Seeds & Perennial & Herbaceous \\
\hline Panicum maximum & Seeds, Rhizome & Perennial & Erect herbaceous \\
\hline Rottboellia exaltata & Seeds (Exclusively) & Annual & Erect herbaceous \\
\hline Senna occidentalis & Seeds (Exclusively) & Annual & Woody shrub \\
\hline Sida cordifolia & Seeds (Exclusively) & Perennial & Erect subshrub \\
\hline Sidastrum micranthum & Seeds (Exclusively) & Perennial & Erect subshrub \\
\hline
\end{tabular}


Of the species cataloged, $55.55 \%$ spread through seeds, $50 \%$ have an annual life cycle and $88.88 \%$ have a herbaceous growth habit (Table 3). According to Lorenzi (2008), approximately $80 \%$ of the weeds present a herbaceous growth habit, corroborating the results of this study. Gulgieri et al. (2009) evaluated the phytosociology of weeds in cassava crop areas in Mato Grosso do Sul and observed a rate of $72.5 \%$ with herbaceous growth habit. In a phytosociological survey in Pompéia, State of São Paulo, were identified 13 weed species of 9 families with distinct mechanisms of reproduction and cycles.

The composition of the infesting community of weeds in the raised area was considered heterogeneous, with 27 species. The families with higher prevalence were Poaceae, Fabaceae and Asteraceae. The species with the highest values of dry weight (g ha ${ }^{1}$ ) were Digitaria sanguinalis $(112,530)$, Brachiaria Brizantha $(98,000)$, Brachiaria decumbens $(73,795)$ and Brachiaria humidicola $(42,780)$.

\section{LITERATURE CITED}

ALBUQUERQUE, J. A. A. et al. Caracterização morfológica e agronômica de clones de mandioca cultivados no Estado de Roraima. R. Bras. Ci. Agr., v. 4, n. 4, p. 388-394, 2009.

ALBURQUERQUE, J. A. A. et al. Interferência de plantas daninhas sobre a produtividade da mandioca (Manihot esculenta). Planta Daninha, v. 26, n. 2, p. 279-289, 2008.

ALBUQUERQUE, J. A. A. et al. Ocorrência de plantas daninhas após cultivo de milho na savana amazônica. Planta Daninha, v. 30, n. 4, p. 775-782, 2012.

AMANULLAH, M. M. et al. Intercropping and Organic Manures on the Growth and Yield of Cassava (Manihot esculenta Crantz.). Res. J. Agric. Biol. Sci., v. 2, n. 5, p. 183-189, 2006.

AGUIAR, E. B. et al. Épocas de poda e produtividade da mandioca. Pesq. Agropec. Bras., v. 46, n. 11, p. 1463-1470, 2011.

BARBOSA, C. Z. R. A. et al. Caracterização de dez clones de mandioca cultivados no Estado de Roraima.

R.Agro@mbiente, v. 1, n. 1, p. 24-27, 2007.
CONCENÇO, G. et al. Phytosociological surveys: tools for weed science? Planta Daninha, v. 31, n. 2, p. 469-482, 2013.

CRUZ, D. L. S. et al. Levantamento de plantas daninhas em área rotacionada com as culturas da soja, milho e arroz irrigado no cerrado de Roraima. R. Agro@mbiente, v. 3, n. 1, p. 58-63, 2009.

\section{EMPRESA BRASILEIRA DE PESQUISA} AGROPECUÁRIA - EMBRAPA. Mandioca: o pão do Brasil (Manioc, le pain du Brésil). Brasília: 2005. 284 p.

FIALHO, C. M. T. et al. Fitossociologia da comunidade de plantas daninhas na cultura da soja transgênica sob dois sistemas de preparo do solo. Sci. Agr., v. 12, n. 1, p. 9-17, 2011.

GIEHL, E. L. H.; BUDKE, J. C. Aplicação do método científico em estudos fitossociológicos no Brasil: em busca de um paradigma. In: FELFILI, J. M. et al. Fitossociologia no Brasil; métodos e estudos de casos. Viçosa, MG: Universidade Federal de Viçosa, 2011. v.1. p. 23-43.

GUGLIERI-CAPORAL, A. et al. Fitossociologia de plantas espontâneas em um mandiocal implantado em pastagem cultivada em Mato Grosso do Sul, Brasil. R. Ci. Agr., n. 51, n. 1, p. 127-141, 2009.

GUGLIERI-CAPORAL, A.; CAPORAL, F. J. M.; POTT, A. Phytosociology of sown pasture weeds under two levels of degradation in Brazilian savanna areas, Mato Grosso do Sul State, Brazil. Pesq. Agropec. Trop., v. 40, n. 3, p. 312-321, 2010. Disponível em: <http://www.cabdirect.org/search.html? q=au\%3A\%22 Guglieri-Caporal\%2C+A.\%22>. Acesso em: 1 mar. 2013.

HUZIWARA, E. et al. Levantamento fitossociológico de plantas daninhas na cultura da mandioca no município de Campos dos Goytacazes, RJ. R. Raízes Amido, v. 5, n. 1, p. 468-472, 2009.

INSTITUTO BRASILEIRO DE GEOGRAFIA E ESTATÍSTICA - IBGE. Produção e produtividade de macaxeira no estado de Roraima. 2012 Disponível em: <http://www.sidra.ibge.gov.br/bda/2012/prevsaf/default>. Acesso em: 5 mar. 2013.

KUVA, M. A. et al. Fitossociologia de comunidades de plantas daninhas em agroecossistema cana-

crua. Planta Daninha, v. 25, n. 3, p. 501-511, 2007.

LORENZI, H. Plantas daninhas do Brasil: terrestres, aquáticas, parasitas e tóxicas. 4.ed. Nova Odessa: Plantarum, 2008. $640 \mathrm{p}$.

MALIK, N. Z. et al. Phytosociological attributes of different plant communities of Pir Chinasi hills of Azad Jammu and Kashmir. Inter. J. Agric. Biol., v. 9, n. 4, p. 569-574, 2007. 
MUELLER-DOMBOIS, D.; ELLEMBERG, H. Aims and methods of vegetation ecology. New York: John Wiley, 1974. 547 p.

PIELOU, E. C. Ecological diversity. New York: John Wiley, 1975. $165 \mathrm{p}$.

PINOTTI, E. B. et al. Levantamento florístico de plantas daninhas na cultura da mandioca no município de Pompéia-SP. R. Raízes Amido, v. 6, n.1, p. 120-125, 2010.

PITELLI, R. A. Interferência de plantas daninhas em cultivos agrícolas. Informe Agropecuário, v.11, n. 1, p. 16-26, 1985.
SCHOLTEN, R.; PARREIRA, M. C.; ALVES, P. L. C. A. Período anterior à interferência das plantas daninhas para a cultivar de feijoeiro 'Rubi’ em função do espaçamento e da densidade de semeadura. Acta Sci. Agron., v. 33, n. 2, p. 313-320, 2011.

SILVA, A. A.; SILVA, J. F. Tópicos em manejo de plantas daninhas. Viçosa, MG: Universidade Federal de Viçosa, 2007. 367 p.

SOUZA, L. A. et al. Morfologia e anatomia da ûor de Pilocarpus pennatifolius Lem. (Rutaceae). R. Bras. Bot., v. 26, n.2, p. 175-184, 2003. 